\title{
HUBUNGAN PENGETAHUAN DAN SIKAP IBU HAMIL MENGENAI STATUS GIZI SELAMA KEHAMILAN
}

\author{
Erike Septa Prautami \\ Akademi Kebidanan Ponpes Assanadiyah Palembang \\ Jl. Banten 6 Kelurahan 16 Ulu Kecamatan Seberang Ulu II Palembang Telp (0711) 510572 \\ Email : erikeseptaprautami@gmail.com
}

\begin{abstract}
Abstrak
Penyebab kekurangan gizi pada ibu hamil karena komsumsi makanan yang tidak memenuhi syarat pemenuhan nutrisi. Status gizi ukuran keberhasilan dalam pemenuhan nutrisi untuk ibu hamil. Tingkat pengetahuan yang rendah menyebabkan ibu tidak mengerti cara pemenuhan gizi yang dibutuhkan ibu hamil selama kehamilannya. Tujuan penelitian ini untuk mengetahui hubungan pengetahuan dan sikap ibu hamil dengan status gizi selama kehamilan di Klinik ABI UMMI DW Sarmadi Palembang. Desain penelitian menggunakan metode Cross Sectional dan teknik pengambilan sampel menggunakan metode Accidental Sampling pada ibu hamil yang datang memeriksakan kehamilan di Klinik ABI UMMI DW Sarmadi Palembang. Instrumen yang digunakan adalah kuesioner dan pengukuran Lingkar Lengan Atas (LILA) dan pengukuran kadar Haemoglobin. Data diolah dengan analisa secara univariat dan bivariat dengan menggunakan chi-square. Hasil dari penelitian adalah pengetahuan ibu hamil dengan status gizi mempunyai hubungan yang bermakna dengan nilai $P$ value 0,001 dan sikap ibu dengan status gizi mempunyai hubungan yang bermakna dengan nilai $p$ value $=$ 0,002. Dari hasil penelitian ini diharapkan kepada petugas kesehatan untuk lebih meningkatkan lagi promosi kesehatan baik berupa penyuluhan kesehatan, pameran kesehatan, iklan-iklan layanan kesehatan dalam upaya pencegahan kekurangan gizi pada ibu hamil.
\end{abstract}

Kata Kunci

: Ibu hamil, Pengetahuan, Sikap, Status gizi

\begin{abstract}
The causes of malnutrition in pregnant women because the consumption of foods that do not meet the nutrition requirements. Nutritional is a measure of the success of nutrition for pregnant women. Low levels of knowledge mother does not understand how to lead fulfilling necessary nutrients pregnant wowen during pregnancy. The purpose of this study to determine the relationship of knowledge and attitudes of pregnant women with nutritional status pregnancy on Klinik ABI UMMI DW Sarmadi Palembang. Design of this study used Cross Sectional method and the accidental sampling technique. Instrument used was a questionaire and measuring antrophometri. The data processed by univariate and bivariate analysis using Chi-square tests. From the bivariat result that variable knowledge spacing has significant association with the nutritional of pregnant women with $p$ value 0,001 and the attitude has significant association with the nutritional of pregnant women with $p$ value 0,002. From the result of this study is expected to further improve health care, moreover promotion in the form education, health exhibition, advertisement of health services in prevention malnutrition in pregnant women.
\end{abstract}

Key Word: Pregnant, Knowledge, Attitude, Nutrition Status

Jurnal Kesehatan dan Pembangunan, Vol.10, No.20, Juli 2020 


\section{PENDAHULUAN}

Masalah Kesehatan Ibu dan Anak (KIA) masih menjadi masalah kesehatan di Indonesia. Hal ini dikarenakan masih tingginya angka kematian ibu dan angka kematian bayi yang ada di Indonesia. Angka Kematian Ibu dan Angka Kematian Bayi di Indonesia merupakan yang tertinggi di ASEAN dengan jumlah kematian ibu tiap tahunnya mencapai 450/100.000 kelahiran hidup yang jauh diatas angka kematian ibu di Filipina yang mencapai 170/100.000 kelahiran hidup, Thailand 44/100.000 kelahiran hidup (Profil Kesehatan Indonesia, 2010).

Gizi ibu Penyebab kekurangan gizi pada ibu hamil karena konsumsi makanan yang tidak memenuhi syarat pemenuhan gizi. Status gizi merupakan ukuran keberhasilan dan pemenuhan nutrisi untuk ibu hamil, tingkat pengetahuan yang rendah menyebabkan ibu tidak mengerti cara pemenuhan nutrisi yang dibutuhkan ibu hamil selama kehamilannya (DepKes, 2010).

Kehamilan memerlukan nutrien yang diperlukan dalam jumlah besar daripada yang dibutuhkan orang dewasa normal karena pada masa hamil pemenuhan status gizi untuk ibu sendiri dan untuk perkembangan bayi yang dikandungnya. Status gizi merupakan ukuran keberhasilan dalam pemenuhan nutrisi untuk ibu hamil. Gizi ibu hamil merupakan nutrisi yang diperlukan dalam jumlah yang banyak untuk pemenuhan gizi ibu sendiri dan perkembangan janin yang dikandungnya (Bobak, Lowdemik dan Jensen, 2005).

Pemeriharaan dan peningkatan kesehatan ibu dan anak merupakan salah satu strategi dalam upaya meningkatkan status kesehatan di Indonesia, hal tersebut merupakan tanggung jawab seluruh tenaga kesehatan khususnya perawat di bidang keperawatan marternitas, terjadinya angka morbiditas ibu dan anak di Indonesia membuktikan pentingnya peningkatan mutu dan pelayanan kesehatan khususnya di bidang martenitas (Oxorn, 2003).

Dalam profil Klinik ABI UMMI DW Sarmadi Tahun 2019 jumlah sasaran ibu hamil 473 orang, pemberian $\mathrm{Fe}_{1}$ dan $\mathrm{Fe}_{3}$ hanya tercapai $50 \%$ dari jumlah ibu yang hamil di Klinik ABI UMMI DW Sarmadi. Berdasarkan data diatas ibu hamil yang memeriksakan kehamilan hanya $50 \%$, tentu banyak ibu hamil yang tidak diketahui keadaan kehamilannya salah satunya status gizi ataupun asupan tablet besi ibu hamil, sehingga masalah ini perlu mendapatkan perhatian khusus.

Berdasarkan studi awal pada bulan Maret 2020 yang dilakukan pada 15 orang ibu hamil didapatkan ada $11 \mathrm{ibu}$ yang tidak mengetahui dan memahami tentang gizi ibu hamil sehingga ibu hamil makan seperti biasa tapi jumlah nasi saja yang lebih banyak, ada 2 orang mengatakn mual dan muntah hal biasa hal ini akan hilang dengan sendirinya, dan ada lagi ibu hamil mengatakan gizi saat hamil sangat lah penting sehingga perlu diperhatikan karena dapat mempengaruhi pertumbuhan janin dan kesehatan ibu.

Berdasarkan hasil studi pendahuluan tersebut maka peneliti tertarik untuk meneliti tentang Hubungan Pengetahuan Dan Sikap Ibu Hamil Mengenai Status Gizi Selama Kehamilan Di Klinik ABI UMMI DW Sarmadi Palembang.

\section{METODOLOGI PENELITIAN Jenis Penelitian}

Penelitian ini merupakan penelitian Kuantitatif dengan Survey Analitik dengan desain penelitian Cross Sectional dengan menggunakan kuesioner. 


\section{Waktu dan Tempat}

Penelitian ini dilakukan di Klinik ABI UMMI DW Sarmadi Palembang Tahun 2020. Proses penelitian ini dilaksanakan pada bulan Januari dengan penyusunan proposal, dan pengumpulan data pada bulan Maret 2020.

\section{Subjek Penelitian}

Populasi dalam penelitian ini adalah seluruh ibu hamil yang datang ke Klinik ABI UMMI DW Sarmadi terhitung mulai dari bulan Januari sampai Maet Tahun 2020 yang berjumlah 115 orang.

\section{Data, Intrumen, dan Teknik Pengumpulan Data}

Data dalam penelitian ini merupakan data primer yang dikumpulkan dengan menggunakan kuesioner dengen teknik wawancara. Dalam pengambilan sampel menggunakan teknik accidental sampling, jumlah sampel pada penelitian ini adalah 30 orang.

\section{Teknik Analisis Data}

Uji statistik yang digunakan adalah uji chi-square, dengan derajat kemaknaan $(\alpha=0,05)$ dengan batas kemaknaan $p$ value $\leq 0,05$ ada hubungan yang bermakna antara variabel pengetahuan dan sikap dan $\mathrm{p}$ value $>0,05$ tidak ada hubungan yang bermakna antara kedua variabel pengetahuan dan sikap.

\section{HASIL PENELITIAN DAN PEMBAHASAN}

Pengetahuan Tabel Distribusi Frekuensi Responden Berdasarkan Pengetahuan

\begin{tabular}{ccrc}
\hline No & Pengetahuan & $\begin{array}{c}\text { Freukue } \\
\text { nsi }\end{array}$ & $\begin{array}{c}\text { Persentase } \\
(\boldsymbol{\%})\end{array}$ \\
\hline 1 & Baik & 15 & 50 \\
2 & Cukup & 15 & 50 \\
\hline & Total & 30 & 100
\end{tabular}

Dari tabel diatas didapatkan pengetahuan responden terbanyak pengetahuan baik 15 orang $(50 \%)$.

\section{Sikap}

Tabel

Distribusi Frekuensi Responden Berdasarkan Sikap

\begin{tabular}{clcc}
\hline No & Sikap & Freukuensi & $\begin{array}{c}\text { Persentase } \\
(\mathbf{\%})\end{array}$ \\
\hline 1 & Positif & 13 & 43.3 \\
2 & Negatif & 17 & 56,7 \\
\hline & Total & 30 & 100 \\
\hline
\end{tabular}

Dari tabel didapatkan sikap responden terbanyak sikap negatip 17 orang $(56,7 \%)$

\section{Status Gizi}

Tabel

Distribusi Frekuensi Responden Berdasarkan Status gizi

\begin{tabular}{clcc}
\hline No & Status gizi & Freukuensi & $\begin{array}{c}\text { Persentase } \\
(\mathbf{\%})\end{array}$ \\
\hline 1 & Baik & 11 & $36.7 \%$ \\
2 & Kurang & 19 & $63,3 \%$ \\
\hline & Total & 30 & 100 \\
\hline
\end{tabular}

Dari tabel diatas didapatkan status gizi responden terbanyak status gizi kurang yaitu 19 orang $(63,3 \%)$.

\section{Hubungan Pengetahuan ibu Hamil dengan Status Gizi Selama Kehamilan \\ Tabel}

Hubungan Pengetahuan Dengan Status Gizi Ibu Hamil Di Klinik ABI UMMI DW Sarmadi

\begin{tabular}{|c|c|c|c|c|c|c|c|c|}
\hline \multirow[t]{3}{*}{ No } & \multirow[t]{3}{*}{ Pengetahuan } & \multicolumn{4}{|c|}{ Status Gizi } & \multicolumn{2}{|c|}{ Total } & \multirow[t]{3}{*}{$\begin{array}{c}\mathbf{P} \\
\text { Value } \\
\end{array}$} \\
\hline & & \multicolumn{2}{|c|}{ Baik } & \multicolumn{2}{|c|}{ Kurang } & & & \\
\hline & & $\mathrm{n}$ & $\%$ & $\mathrm{n}$ & $\%$ & n & $\%$ & \\
\hline 1 & Baik & 9 & 60 & 6 & 40 & 15 & 100 & \\
\hline \multirow[t]{2}{*}{2} & Kurang & 2 & 13,3 & 13 & 86,7 & 15 & 100 & $\mathbf{0 , 0 2 3}$ \\
\hline & Total & 11 & 36,7 & 19 & 63.3 & 30 & 100 & \\
\hline
\end{tabular}
responden yang pengetahuan baik terdapat 9 orang $(60 \%)$ berada pada status gizi baik, dari 15 responden berpengetahuan kurang ada 2 orang $(13,3 \%)$ status gizi baik.

Dari uji statistik Chi Square didapatkan nilai p value sebesar 0,008 yang 
berarti nilai $\mathrm{p}$ value lebih kecil dari nilai $\alpha$ 0,05, maka dapat dapat disimpulkan terdapat hubungan yang bermakna antara pengetahuan ibu hamil dengan status gizi ibu hamil di Klinik ABI UMMI DW Sarmadi.

Hubungan Sikap Ibu Hamil dengan Status Gizi Selama Kehamilan

Tabel

Hubungan sikap Dengan status gizi ibu hamil Di Klinik ABI UMMI DW Sarmadi

\begin{tabular}{|c|c|c|c|c|c|c|c|c|}
\hline \multirow{3}{*}{ No } & \multirow{3}{*}{ Sikap } & \multicolumn{4}{|c|}{ Status Gizi } & \multirow{2}{*}{\multicolumn{2}{|c|}{ Total }} & \multirow{3}{*}{$\begin{array}{c}\mathbf{P} \\
\text { Value }\end{array}$} \\
\hline & & \multicolumn{2}{|c|}{ Baik } & \multicolumn{2}{|c|}{ Kurang } & & & \\
\hline & & $\mathbf{n}$ & $\%$ & $\mathbf{n}$ & $\%$ & n & $\%$ & \\
\hline 1 & Positif & 9 & 69.2 & 4 & 30.8 & 13 & 100 & \\
\hline \multirow[t]{2}{*}{2} & Negatif & 2 & 11.8 & 15 & 88.2 & 17 & 100 & 0,002 \\
\hline & Total & 11 & 36,7 & 19 & 63.3 & 30 & 100 & \\
\hline
\end{tabular}

Dari tabel diatas sebanyak 13 responden yang mempunyai sikap positif terdapat 9 orang ibu hamil $(69,2 \%)$ berada pada status gizi baik, sebanyak 17 responden mempunyai sikap negatif terdapat 2 orang ibu hamil $(11,8 \%)$ yang ber status gizi baik.

Dari hasil uji statistik Chi Square didapatkan nilai $\mathrm{p}$ value sebesar 0,002 yang berarti nilai $\mathrm{p}$ value lebih kecil dari nilai $\alpha$ 0,05, maka dapat dapat disimpulkan terdapat hubungan yang bermakna antara sikap ibu hamil dengan status gizi ibu hamil di Klinik ABI UMMI DW Sarmadi.

\section{Pembahasan}

\section{Hubungan Pengetahuan dengan Status} Gizi Ibu Hamil Selama Kehamilan.

Analisa hubungan pengetahuan dengan status gizi ibu hamil dengan uji statistik Chi-Square didapatkan nilai p value sebesar 0,001 yang berarti nilai $\mathrm{p}$ value lebih kecil dari nilai $\alpha 0,05$, maka dapat dapat disimpulkan terdapat hubungan yang bermakna antara pengetahuan dengan status gizi ibu hamil di Klinik ABI UMMI DW Sarmadi.
Pengetahuan yang dimiliki oleh seorang ibu akan berpengaruh terhadap perilaku seseorang. Jika ibu mempunyai pengetahuan yang baik kemungkinan akan memberikan asupan gizi yang cukup untuk dirinya dan janinnya, sebaliknya jika ibu mempunyai pengetahuan yang kurang kemungkinan kebutuhan asupan gizi untuk diri dan janinnya tidak akan tercukupi secara maksimal (Amirudin, 2007).

Hasil penelitian ini juga didukung oleh penelitian Muslihatun (2009), dengan judul "Hubungan Pengetahuan dengan Umur Ibu Hamil Terhadap Status Gizi di Puskesmas Gandus Palembang" Hasil penelitian hubungan antara pengetahuan dan status gizi didapatkan nilai $\mathrm{p}$ value 0,000 yang artinya ada hubungan yang signifikan antara pengetahuan terhadap status gizi ibu hamil.

Hasil penelitian ini juga didukung oleh penelitian Muslihatun (2009), dengan judul "Hubungan Pengetahuan dengan Umur Ibu Hamil Terhadap Status Gizi di Puskesmas Gandus Palembang" Hasil penelitian hubungan antara pengetahuan dan status gizi didapatkan nilai $\mathrm{p}$ value 0,000 yang artinya ada hubungan yang signifikan antara pengetahuan terhadap status gizi ibu hamil

Kebutuhan gizi selama kehamilan akan meningkat setiap hari, orang Indonesia sudah banyak yang mengetahui manfaat gizi bagi ibu hamil namun sampai saat ini masih banyak ibu hamil yang mengalami masalah gizi saat hamil. (Damaik. R, 2009).

Berdasarkan hasil penelitian ini pengetahuan memiliki hubungan yang signifikan terhadap status gizi selama kehamilan. Hal ini disebabkan karena ibu hamil sudah mengetahui tentang gizi yang baik selama hamil sehingga ibu akan bersikap kooperatif terhadap apa yang dianjurkan bidan, perawat dan tim gizi. Ibu hamil yang kooperatif akan menunjang

Jurnal Kesehatan dan Pembangunan, Vol.10, No.20, Juli 2020 
keberhasilan dalam mengatasi masalah anemia dan kekurangan gizi kronis (KEK) tercapai.

\section{Hubungan Sikap dengan Status Gizi Ibu Hamil}

Berdasarkan Hasil uji statistik Chi Squere didapatkan nilai $\mathrm{P}$ value sebesar 0,02 yang berarti nilai $\mathrm{p}$ value lebih kecil dari $\alpha$ $(0,05)$, hal ini menunjukkan ada hubungan bermakna antara sikap dan status gizi pada ibu hamil.

Menurut Allport dalam Azwar (2007) Sikap terbentuk dari kepercayaan atau keyakinan, ide dan konsep terhadap objek artinya bagaimana pendapat atau pemikiran seseorang terhadap objek, kemudian diikuti oleh penilaian terhadap objek tersebut yang akan memberikan kecendrungan untuk bertindak. Ini berarti bahwa sebelum menentukan sikapnya seseorang terlebih dahulu harus mengetahui tentang objek itu sendiri, yang pada akhirnya akan menentukan ke arah mana sikap mereka apakah sikap positip atau sikap negatip.

Hal ini sesuai dengan penelitian yang dilakukan di manado oleh Anastasia dkk (2013) dengan uji statistik Chi Square didapatkan nilai $\mathrm{P}$ value sebesar 0,03 , bahwa terdapat hubungan yang signifikan antara sikap dan status gizi.

Hal ini sejalan dengan penelitian yang dilakukan Yanti. E (2010) dengan hubungan pengetahuan dan sikap mengenai kecukupan gizi pada ibu hamil dan uji stastistik Chi Square dari variable sikap ibu hamil didapatkan nilai $\mathrm{P}$ value sebesar 0,007 .

Berdasarkan hasil penelitian ini didapatkan ibu yang bersikap positip banyak berstatus gizi baik dan sebaliknya ibu yang bersikap negatip banyak berstatus gizi kurang sehingga sikap mempunyai hubungan yang signifikan terhadap status gizi selama kehamilan, ibu hamil yang berkunjung atau melakukan Antenatal Care (ANC) ke puskesmas diberikan penyuluhan tentang gizi yang baik saat hamil tetapi masih ada ibu yang bersikap negatip sehingga ibu hamil yang tidak mendukung (bersikap negatip) setelah dilakukan pengukuran kadar $\mathrm{Hb}$ dan lingkar lengan atas (LILA) berstatus gizi kurang maka ibu hamil ini akan beresiko mengalami anemia dan kekurang energy kronis (KEK) sedangkan dampak dari status gizi kurang dapat menyebabkan abortus, Berat Bayi Lahir Rendah (BBLR), pendarahan saat melahirkan dan lain-lain.

\section{KESIMPULAN}

Berdasarkan hasil penelitian tentang hubungan pengetahuan dan sikap ibi hamil mengenai status gizi selama kehamilan 30 responden di Klinik ABI UMMI DW Sarmadi, maka dapat diambil kesimpulan sebagai berikut:

1. Rata-rata pengetahuan responden baik dan kurang 12 orang (40\%)

2. Rata-rata sikap responden Sikap negatip ada 17 orang $(56,7 \%)$

3. Rata-rata Satus gizi responden status gizi kurang yaitu 19 orang $(63,3 \%)$

4. Terdapat hubungan yang bermakna antara pengetahuan ibu hamil dengan status gizi selama kehamilan dengan $\mathrm{p}$ value $=$ 0,008 .

5.Terdapat hubungan yang bermakna antara sikap ibu hamil dengan status gizi selama kehamilan dengan p value $=0,002$.

\section{SARAN}

untuk $\begin{gathered}\text { Diharapkan peneliti selanjutnya } \\ \text { meneliti hubungan dalam }\end{gathered}$ meningkatkan pelaksanaan status gizi pada ibu hamil dengan rancangan desain dan metode penelitian yang berbeda. Serta hasil penelitian ini berguna untuk menambah pengetahuan dan pengalaman dalam 
melakukan penelitian dalam cakupan yang lebih luas dengan melakukan penelitian pada variabel-variabel lainnya yang belum diteliti misalnya faktor pendidikan, umur, social ekonomi, budaya, dan paritas ibu.

\section{UCAPAN TERIMA KASIH}

Terima kasih kepada Akbid Ponpes Assanadiyah Palembang yang telah memberikan dukungan selama proses penelitian ini berlangsung.

\section{DAFTAR PUSTAKA}

Agus Riyanto. (2009) Pengolahan dan analisis data kesehatan.Yogjakarta : Muha Medika

Anastasia P. G. Goni dkk. (2013) Hubungan Pengetahuan dan Sikap Ibu Hamil terhadap Status Gizi Puskesmas Bahu Kota Manado. Ejurnal Keperawatan Volume 1 no. 1 Agustus 2013.

Arikunto. (2010). Prosedur penelitian, Sistem Pendekatan Praktek, Jakarta : Rineka Cipta.

Arisman.(2005). Gizi dalam Daur Kehidupan. Edisi 2, Jakarta : EGC

Azwar. (2013). Sikap Manusia, Teori dan Pengukurannya, Yogjakarta : Pustaka Pelajar.

Bobak, Lowdermilk \& Jensen. Keperawatan Martenitas, Edisi 4, Jakarta : EGC

Budiman dan Agus Riyanto, (2013). Kapita Selekta Kuesioner Pengetahuan dan sikap dalam penelitian Kesehatan, Jakarta : Salemba Medika.

Dara Masita, (2011). Hubungan antara pengetahuan dan sikap dengan kepatuhan ibu hamil dalam mengkomsumsi tablet $\mathrm{Fe}$ di Puskesmas Swakelola Kenten, Palembang.

Departemen Gizi dan Kesehatan Masyarakat (2007). Gizi dan Kesehatan Masyarakat. Jakarta : PT Raja Grafindo Persada

Dinas Kesehatan Sumatera Selatan, (2010). Profil Kesehatan : Dinkes di akses pada tanggal 20 oktober 2013.

Handoko Riwidikdo.(2010) Statistik untuk Penelitian Kesehatan dengan Aplikasi Program $R$ dan SPSS. Yogjakarta : Pustaka Rihama

Haniyani,. (2011). Gizi untuk Kesehatan dan Anak. Yogyakarta: Graha ilmu

Hidayat, Ratna (2009). Asuhan Keperawatan pada Kehamilan Fisiologis dan Patologis.Jakarta : Salemba Medika.

Kristiyanasari, Weni. (2010) Gizi Ibu Hamil, Yogjakarta : Medical Book.

Muslihatun, (2011). Hubungan pengetahuan dan umur dengan status gizi ibu hamil di Puskesmas Gandung Palembang. Stikes Muhammadiyah Palembang.

Mutalazimah. (2005). Hubungan LILA dan Kadar Haemoglobin Ibu Hamil dengan Berat Bayi Lahir di RS Moewardi Surakarta. Volume 6, no 2, $2005:$ : 114-126.

Notoatmodjo, S. (2012). Metedologi Penelitian Kesehatan. Jakarta : Rineka Cipta. 
Notoatmodjo. S. (2010). Ilmu Kesehatan Masyarakat. Jakarta : Rineka Cipta

Kesehatan. Vol 15, No 1. Juni 2011 : 31-16.

Sugiyono. (2008). Metode Penelitian Kuantitatif Kualititatif Dan $R \& D$. Bandung : Alfabeta.

Sunita Almatsier dkk. (2011). Gizi Seimbang dalam daur kehidupan, Jakarta : PT> Gramedia Pustaka Utama Jakarta

St, Fatimah Dkk. (2011) Pola Komsumsi dan Kadar haemoglobin pada Ibu Hamil di Kabupaten Maros, Sulawesi Selatan. Makara,

Sarwono Dkk. (2009). Metode Penelitian Bandung: Alfabeta. Bina Pustaka Sarwono Prawirohardjo.

Syaifudin, (2010). Keperawatan dan Kebidanan dengan SPSS. Yogjakarta : grafindo Litera Media.

Saipudin. (2009) Pelayanan Kesehatan Maternal dan Neonatal. Jakarta : PT.

Satiti (2011). Hubungan Pengetahuan dan Sikap mengenai Kecukupan Gizi pada Ibu Hamil di Kecamatan Jebres Surakarta.

Nursalam. (2008). Konsep dan Penerapan Metodelogi Penelitian Ilmu Keperawatan. Surabaya : Salemba Medika.
Wiknjosastro (2005). Ilmu Kebidanan. Jakarta : Yayasan Bina Pustaka Sarwono Prawiroharjo Syaifudin, (2010). Keperawatan dan Kebidanan dengan SPSS. Yogjakarta : grafindo Litera Media.

Satiti (2011). Hubungan Pengetahuan dan Sikap mengenai Kecukupan Gizi pada Ibu Hamil di Kecamatan Jebres Surakarta.

Wiknjosastro (2005). Ilmu Kebidanan. Jakarta : Yayasan Bina Pustaka Sarwono Prawiroharjo 